\title{
Phenotypic and genetic differentiation in young-of-the-year common sole (Solea solea) at differentially contaminated nursery grounds
}

\author{
Bruno Guinand ${ }^{a, d,}{ }^{*}$, Eric D.H. Durieux ${ }^{b}$, Célie Dupuy ${ }^{a}, 1$, Frédérique Cerqueira ${ }^{c}$ and Marie-Laure \\ Bégout $^{\mathrm{b}}$
}

\author{
a Université Montpellier II, Institut des Sciences de l'Evolution de Montpellier, Evolution des Poissons, \\ CNRS UMR 5554, place E. Bataillon, c.c. 63, 34095 Montpellier, Cedex 5, France \\ ${ }^{\mathrm{b}}$ IFREMER, Place Gaby Coll, BP5, 17137 L'Houmeau, France \\ ${ }^{c}$ Université Montpellier II, IFR119 Montpellier Environnement Biodiversité, place E. Bataillon, c.c. 63, \\ 34095 Montpellier, Cedex 5, France \\ ${ }^{d}$ Station Méditerranéenne de l'Environnement Littoral, quai de la Daurade, 34200 Sète, France \\ ${ }^{1}$ Present address: Laboratoire des Sciences de l'Environnement Marin (LEMAR), UMR 6539 \\ CNRS/IRD/UBO, Institut Universitaire Européen de la Mer (IUEM), Technopole Brest Iroise, Place \\ Nicolas Copernic, 29280 Plouzané, France.
}

*Corresponding author: Bruno Guinand, Tel.: +33 (0) 4671446 87; fax: +33 (0) 46714 45 54, email address : bruno.guinand@univ-montp2.fr

\begin{abstract}
:
Growth-related characters, condition factor, and genetic differentiation were investigated for a single cohort of young-of-the-year (YOY) sole within and among nurseries with differing levels of heavy metals ( $\mathrm{Cd}, \mathrm{Cu}$ and $\mathrm{Zn}$ ) contamination in the two Charentais Straits, Bay of Biscay, France. Analyses were performed when individuals recruited (May), then after a full summer spent in each nursery (October). Levels of phenotypic and genetic diversity were compared, together with genetic differentiation at a candidate metallothionein $(M T)$ locus and three putatively neutral microsatellite loci. No phenotypic or genetic differentiation was detected among nurseries in May, but significant variation at each phenotypic trait and at the multilocus level in October $(P<0.001)$. Single locus analysis demonstrated that only the $M T$ locus was significantly differentiated among nurseries, whether corrected for null alleles or not $\left(\theta=0.0401\right.$ and $\theta_{\text {corr.FreNA }}=0.0326$, respectively; $P<0.001)$. Results indicate that phenotypic differences among YOY sole nurseries present a molecular correlate acting at identical spatio-temporal scales among nurseries, potentially reflecting differential selective pressure among nurseries in response to contamination.
\end{abstract}

\section{Highlights}

Sole is an important commercial species inhabiting polluted coastal areas and estuaries. The Charentais Straits are differentially affected by heavy contamination. Juvenile sole's phenotypes are differentially impaired over nurseries after colonisation. Genetic differentiation at a metallothionein locus parallels phenotypic change.

Keywords: Solea solea; Nursery; Bay of Biscay; Metallothionein 


\section{INTRODUCTION}

Coastal ecosystems are among the most productive areas in the world (Costanza et al., 1997), but, together with global warming, they suffer various anthropogenic pressures such as pollution, eutrophication, overexploitation, exotic species introduction, and habitat transformation (Harley et al., 2006; Lotze et al., 2006; Airoldi and Beck, 2007; Díaz and Rosenberg, 2008; Halpern et al., 2008). In demersal fishes, estuaries and coastal areas act as essential habitats for early life stages (Miller et al., 1984; Beck et al., 2001). These species exhibit higher growth rates and better survival in the productive shallow waters (Beck et al., 2001). Hence, the available surface area and quality of such habitats may have a considerable influence on recruitment and sustainability of a species or a fishery (Gibson, 1994; Dahlgren et al., 2006; Courrat et al., 2009).

In the past twenty years, numerous studies have evaluated the impact of human disturbance on biological organisation of coastal ecosystems, and habitat quality of demersal species, in the French coastal waters of the Bay of Biscay, North Eastern Atlantic (increasing temperature: Poulard and Blanchard, 2005; Hermant et al., 2010; over-exploitation: Désaunay et al., 2006; estuarine pollution: Marchand et al., 2003, Munaron et al., 2006; eutrophication: Chapelle et al., 1994). Flatfish, especially the common sole (Solea solea), have received particular attention. For sole, the spawning biomass in the Bay of Biscay stock has been declining since 1993 and it is currently considered to be at risk (Anonymous, 2005). The main nursery grounds are located in estuaries and bays (Koutsikopoulos et al., 1989; Le Pape et al., 2003a, 2003b); comparison of various biological indicators (e.g. morphometric and lipid condition, growth and density) have revealed quality differences between sole nurseries that result from a complex combination of factors such as temperature, hypoxia, salinity, density, river input, food availability, pollution, and parasitism (Le Pape et al., 2003b, 2003c; 
Claireaux et al., 2004; Gilliers et al., 2006a, 2006b; Amara et al., 2007; Laffargue et al., 2007, Durieux et al., 2007, 2010a, and references therein).

If biotic and abiotic constraints affecting juvenile fishes are well identified in nurseries, relationships with genetic diversity has been poorly investigated. Correlation among gene diversity distribution (or differentiation) and observed phenotypic distribution has to be investigated to understand to the relative ecological success of natural populations when facing environmental constraints. For the Bay of Biscay and English Channel estuaries, several studies have indicated possibly adaptive genetic differentiation in the European flounder (Platichthys flesus), as particular alleles/genotypes were correlated to proxies of fitness such as condition factor or fecundity (Laroche et al., 2002; Marchand et al., 2003, 2004). In this panmictic species, significant genetic differentiation was recorded at some candidate loci, suggesting a role for selection (Marchand et al. 2010). In Bay of Biscay sole, Guinand et al. (2008) proposed a model linking global panmixia and local genetic differentiation due to selective processes occurring while individuals were in contaminated nurseries. Nevertheless, this model (1) has to be tested to prove that sole are not genetically differentiated at the onset of nursery colonisation, but become so at specific loci possibly after encountering a nursery-specific stress (i.e. a temporal component), (2) that differentiation occurs among contaminated grounds where pollutants are differentially accessible to fish (i.e. a spatial component in bioavailability), then (3) that this correlates phenotypic differentiation for traits that may drive fitness of local populations.

In the Bay of Biscay, the Charentais Straits represent an interesting area to investigate the spatio-temporal dynamics of both genetic and phenotypic differentiation at a local scale in sole. Based on young-of-the-year (YOY; 0-group) sole density, the Charentais Straits are estimated to be the most important sole nursery grounds along the French Atlantic coast (Le Pape et al., 2003b). Compared to the neighbouring Pertuis 
Breton, the Pertuis d'Antioche and the Marennes Oléron bay have been shown to be more impacted by cadmium (Cd) coming from the southern Gironde estuary and trapped in the upper layer of the sediment (Boutier et al., 2000; Pigeot et al., 2006; Dabrin et al. 2009) (Fig. 1). It has been estimated that $\approx 500 \mathrm{~kg}$ of dissolved Cd reach the MarennesOléron bay through the Pertuis of Maumusson each year (Boutier et al., 2000) (Fig. 1). A similar flux certainly exists for other metals such as zinc (Zn), but it far less documented quantitatively. Accumulation in and transfer of heavy metals from the nearby Gironde estuary is known to seriously affect organisms such as fishes (Durrieu et al., 2005), shrimp (Béguer et al., 2008), or oysters (Mouneyrac et al., 1998). The Pertuis Breton is not directly influenced by outputs from the Gironde estuary, but is directly influenced by sea currents due to its wide western entrance (Salomon, 1995, cited by DardignacCorbeil, 2004). The Pertuis Breton area hence appears less impacted by Cd than the Pertuis d'Antioche. For the year 1999, it was reported an average Cd concentration of $\approx 0.18$ and $\approx 0.33 \mu g . g^{-1}$ dry weight in the upper sediment layer of Pertuis Breton and Pertuis d'Antioche, respectively (computed using data available in Ifremer 2005). If difference in Cd concentration in the sediment is still limited, the bioavailability of Cd to organisms was demonstrated highly different across straits. Miramand et al. (2000) reported a 10 -fold decrease in Cd concentration in tissues of wild oysters between the Gironde estuary and La Rochelle, and more than a twenty fold decrease in concentration compared to the central zone of the Pertuis Breton (Fier d'Ars; Fig. 1). Amiard et al. (2007) also reported that Cd bioavailability differed between the two Charentais Straits for several benthic macroinvertebrates, as the lability of sediment bound metals such as Cd was up to ten times higher among locations from Pertuis d'Antioche (south of La Rochelle) and Pertuis Breton (Fiers d'Ars; Fig. 1). Differential bioavailability of other heavy metals to organisms has also been reported, including $\mathrm{Zn}$ or copper $(\mathrm{Cu})$ (e.g. Roméo et al. 2003; Ifremer 2006; Amiard et al. 2007). 
In marine fishes, it is established that most metals enters mainly through the intestine during drinking (Wang and Rainbow, 2008), but also through the gills (McDonald and Wood, 1993; Pierron et al., 2007). The profound physiological effects that sediment quality can exert on sole and other benthic fish which inhabit mud flats have been widely investigated (e.g. Moles and Norcross, 1998; Couturier et al., 2007). In flatfish, Cd concentrations in the liver were tightly positively correlated to concentrations of Cd in water and sediment (P. flesus: Sulaiman et al., 1991; S. solea: Usero et al., 2003; S. senegalensis: Costa et al., 2009) and to Cd bioavailability (Costa et al., 2009).

MT is involved in cellular detoxification of heavy metals, binding to ions such as Zn, $\mathrm{Cu}$, and especially Cd (Klaasen et al., 1999; Beattie et al., 2005). It also has pleiotropic metabolic actions in, for example, regulation of energy balance, growth, behaviour, and reproduction of fishes (Olsson et al., 1995; Coyle et al., 2002; Lewis et al., 2006; Vergani et al., 2009). In fish (Brachydanio rerio; Chen et al., 2004), flatfish (George et al., 1996), and especially in soleids (Solé Rovira et al., 2005), induction of MT gene expression at early developmental stages can cause depletion of antioxidant defences and stress proteins, possibly decreasing their fitness. In this context, a metallothionein (MT) locus revealed significant genetic differentiation among nurseries separated by >100km (Gironde and Pertuis d'Antioche vs other Bay of Biscay estuaries; Guinand et al. 2008). This locus is therefore an interesting candidate to investigate relationships among patterns of genetic diversity (or differentiation) and fitness-related characters.

The aims of this study were to investigate spatio-temporal variability of some growth-related characters, condition factor, and genetic differentiation in a single cohort of YOY soles within and among the Pertuis d'Antioche (high input and larger bioavailability of heavy metals like $\mathrm{Cd}, \mathrm{Zn}$ and $\mathrm{Cu}$ ) and the Pertuis Breton (lower bioavailability) nurseries. We contrasted genetic variation at locus $M T$ and three putative 
neutral microsatellite loci. Levels of gene diversity and genetic differentiation were compared at the settlement of YOY soles in each nursery (May), and after a full summer spent in the nursery (October), when impacts have presumably accumulated on individuals during the summer season (Laffargue et al., 2007).

\section{MATERIALS AND METHODS}

\subsection{Field sampling}

YOY sole were sampled in May $\left(23-24^{\text {th }}\right)$ and October $2005\left(4-5^{\text {th }}\right)$ at four and three sampling sites in the two main areas of the macrotidal Charentais Straits: Pertuis Breton and Pertuis d’Antioche (Fig. 1) as part of a quantitative survey (Durieux et al., 2010a). A more complete description of these straits is given in Durieux et al. (2010a). YOY sole are known to colonise the Charentais Straits on a single occasion (i.e. as a single larval pulse) from April to June, depending on environmental conditions that modulate the reproduction of spawners, and the early growth and metamorphosis of larvae (Dorel et al., 1991; Amara et al., 2000). Sites were identified by GPS so that May and October samplings were performed at the same locations. Fishing was done at low tide using a standard beam trawl ( $2 \mathrm{~m}$ wide and $0.40 \mathrm{~m}$ high, mounted with a $5 \mathrm{~mm}$ stretched mesh net in the cod end) at around $2 \mathrm{~m}$ depth and at 2.5 knots for 20 min. After each fishing day, fish were brought back to the laboratory, and tissue samples (white muscle and fin pieces) were collected and stored in $95^{\circ}$ ethanol for further genetic analyses. A total of 233 individuals were randomly sub-sampled for genetic analyses and biological variable measurements. Details on fish collections are given in Table 1. Mud-flat sediment is present at each sampling site, except for the sandy sites B1 and B2 closer from the Arçay Spit (Fig. 1). 


\subsection{Biological variables and data analysis}

Total and standard length (TL and SL respectively; in mm) and wet body mass (W, in g; W for 'weight' to avoid confusion with another acronym introduced below) were measured for each individual at each date (May and October). Fulton's condition index $\left(\mathrm{g} . \mathrm{cm}^{-3}\right)$ was calculated individually as $K=(\mathrm{W} \times 100) / \mathrm{SL}^{3}$, with $\mathrm{W}$ in $\mathrm{g}$ and SL expressed in $\mathrm{cm}$. Normality of the distribution of each variable was tested using the Kolmogorov-Smirnov test (including Lilliefors correction), then homoscedasticity using the Bartlett test (for samples with $n>15$ only; Table 1) after pooling all sites of Pertuis Breton and Pertuis d'Antioche at each date. Normally distributed samples among the Pertuis Breton and Pertuis d'Antioche sites were regrouped according to Scheffé's posthoc test and data were log transformed to meet homogeneity of variances. Once Pertuis Breton and Pertuis d'Antioche samples were grouped, means and standard deviations were computed for each variable. For each sampling period, means of the investigated variables were further compared using one-way ANOVA followed by Tukey’s post-hoc test.

\subsection{Genotyping}

Pieces of preserved tissue were analyzed for genetic variation (length polymorphism) at the MT intronic locus first described in Rolland et al. (2007), and at three microsatellite loci (Sos3, Sos6, Sos11) described by Garoia et al. (2006). Tissues were digested in $100 \mu \mathrm{l}$ lysis buffer containing $25 \mu \mathrm{l}$ 0.5M EDTA (pH=8), $2.5 \mu \mathrm{l}$ RNAse $\left(4 \mathrm{mg}^{\mathrm{m}} \mathrm{m}^{-1}\right)$, and $10 \mu \mathrm{l}$

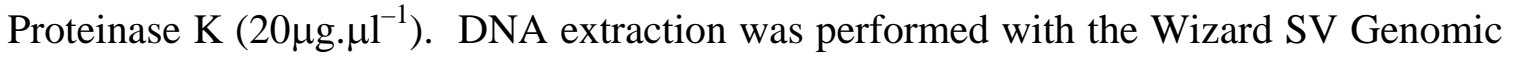
DNA Purification System kit (Promega Corporation, Madison, WI, USA), according to manufacturer recommendations. Extracts were stored to $-20^{\circ} \mathrm{C}$. Individual PCR amplifications were performed according to Garoia et al. (2006) for microsatellite loci, and to Rolland et al. (2007) for locus MT. The MT reverse primer was however changed 
(5’-CCGCAGTTGCAGTTTCCAGCT-3’; forward primer unchanged), resulting in better amplification, and less cycles necessary during PCR (25 cycles instead of 35, initially, without affecting the outcomes of genotyping, B. Guinand, C. Dupuy, pers. obs.). Genotyping of individuals was performed by allele sizing on an ABI PRISM ${ }^{\circledR} 3700$ DNA Analyzer (Applied Biosystems), using 5'-labelled forward primers and the GeneScanTM-500 LIZ ${ }^{\circledR}$ size standard (Applied Biosystems) as internal size standard. Data were analysed with the GeneMapper v4.0 software in order to define individual genotype at each locus. This analysis was performed independently by three of us (BG, $\mathrm{CD}, \mathrm{FC})$ to enhance the reliability of results. Individuals that lead to different allele scorings ( $\approx 6 \%$ of total observations, equally distributed over loci) were systematically reamplified and re-analysed until identical scoring was independently shared by observers.

\subsection{Genetic data analysis}

Deviations from Hardy-Weinberg expectations (HWE) within samples were investigated using Weir and Cockerham's (1984) estimate of $f$ (quoted as $\hat{f}$ ) with Genetix (v.4.05; Belkhir et al. 2001; http://www.univ-montp2.fr/ genetix/). The number of alleles and the observed gene diversity ( $H_{\text {obs; }}$ Nei 1987) for each population and locus were also computed by Genetix v4.05. Test of the null hypothesis of no significant departure from HWE ( $\hat{f}=0$ ) was performed by randomly permuting alleles from the original matrix of genotypes using the appropriate procedure in Genetix v4.05. When departure of HWE expectation was detected, we used the MicroChecker program (van Oosterhout et al., 2004) to determine whether deviation from panmixia could be due to the presence of null alleles (alleles not amplified by PCR because of nucleotide variations in the regions to which primers were designed to bind) or to genotyping errors. Linkage disequilibrium (non-random association of alleles at different loci) was checked following Weir (1979), also using Genetix v4.05. 
Pairwise levels of population differentiation were investigated using Weir and Cockerham's (1984) $\hat{\theta}$, an estimator of Wright's (1951) $F_{\text {st }}$ implemented in Genetix. We calculated pairwise estimators by applying the ENA correction (for 'excluding null allele') proposed by Chapuis and Estoup (2007), and provided by the FreeNA package (http://www.montpellier.inra.fr/URLB/) to correct for possible bias in estimate of population differentiation due to the presence of null alleles. Indeed, $F_{\mathrm{st}}$ is overestimated in the presence of null alleles (Paetkau et al., 1997). In order to perform robust testing of population differentiation, a maximum-likelihood (ML) estimate was then calculated for the frequency of null alleles (Dempster et al., 1977); this ML estimate was shown to accurately estimate null allele frequency compared to other methods (Girard and Angers, 2008). As in Fratini et al. (2008), only loci that were found to have a possible null allele identified with MicroChecker analysis were reanalyzed for genetic differentiation using the ENA correction.

\subsection{Simulated data sets}

A correlate of the correction (i.e. adding one allele whose frequency is estimated with a ML procedure at individual loci presenting a null allele) is that two data sets can be considered: uncorrected vs null-allele corrected. Estimates of gene diversity and genetic differentiation are different among data sets due to consideration of new alleles. We took advantage of the corrected allele frequency distributions to simulate data for each population (AM, AO, BM, BO in Table 1; see Section 3.2 for justification that initial samples B1 to B4, and A1 to A3 were not retained). Simulations allowed comparisons of (i) corrected and uncorrected estimates of $H_{\mathrm{obs}}$ within each population, and (ii) corrected $H_{\mathrm{obs}}$ estimates across populations and time periods. Indeed, $H_{\mathrm{obs}}$ based on raw, uncorrected data resumes to only few values (one per sample) for which statistical analysis is fairly limited. Under random mating, we first generated 1,000 individuals 
following each corrected allelic distribution, and randomly picked individuals in these simulated distributions. For each population, twenty-five replicates have been carried out, with sizes of samples equal to the initial size of each population (Table 1). We limited ourselves to twenty-five replicates as variance among simulated data sets was shown to be fairly stable after as few as twelve to fifteen replicates. Using $t$-tests, we established if the original, uncorrected value of $H_{\mathrm{obs}}$ ( $H_{\mathrm{obs}}$ uncorr. $)$ significantly differed from the corrected values of $H_{\text {obs }}$ ( $\bar{H}$ obs corr., we use the superscript “-” to indicate the mean over the simulated samples) at each locus. Comparison of $\bar{H}$ obs corr among samples were analysed by one-way ANOVA (25 independent replicates). The multilocus estimates of $\bar{H}$ obs corr. $( \pm \mathrm{SD})$ in each population were also estimated.

In parallel, three estimates of $F_{\text {st }}$ were considered: uncorrected $(\hat{\theta})$, corrected as computed by FreeNA $\left(\hat{\theta}_{\text {corr.FreeNA }}\right)$, and corrected as estimated by the mean of genetic differentiation over the twenty-five randomly replicated samples for each population $\left(\bar{\theta}_{\text {corr.repl. }}\right) . \quad \hat{f}$ values for the null-allele corrected data sets were checked in order to appreciate the robustness of simulations and then to verify that new estimates were not different from zero, as expected when any effect for null allele is removed.

\section{RESULTS}

\subsection{Biological data}

For each date (May and October), the KS and the Bartlett tests on log-transformed data revealed normality and homoscedasticity, respectively, after grouping samples from the Pertuis d'Antioche together. Hence, original samples A1, A2 and A3 were not statistically distinct for any variable. Pertuis d'Antioche samples were then pooled in further analyses. Conversely, results from such tests and the Sheffé post-hoc test 
indicated that individuals in sample B1 behaved differently from other Pertuis samples (B2, B3 and B4) for each variable. The B1 sample consistently reported significantly lower TL, SL, and W, but larger condition factor in both May and October when compared to the B2, B3 and B4 samples (Table 2); indicating this sample has to be treated separately. Three groups have then been defined based on analysis of phenotypic data: A1-A2-A3, B2-B3-B4, and B1.

Results reporting means ( \pm SD) of each recorded variable are summarised in Table 2 and Fig.2 for each group of samples. Mean values were similar to those recorded in previous investigations that merely dealt with the Pertuis Breton area (Gilliers et al., 2006a; Durieux et al., 2007; Laffargue et al., 2007). For instance, similar values of $K<$ 1.2 g.cm $^{-3}$ (Fig. 2) were reported in Durieux et al. (2007) and Laffargue et al. (2007). Total length was, however, slightly lower in October at Pertuis Breton (TL $\approx 110 \mathrm{~mm}$; Table 2), compared to other studies (e.g. TL $\approx 130 \mathrm{~mm}$ for both the 1999 and 2000 YOY cohorts; Laffargue et al. 2007). In May, no significant difference ( $P>0.05)$ was recorded at each investigated variable between the Pertuis Breton (B2, B3, B4) and the Pertuis d'Antioche samples (Table 2). Concurrently, in May, the B1 sample significantly differed from both the other Pertuis Breton and Pertuis d'Antioche samples for all investigated variables (all $P<0.01$ ) (Table 2; Fig. 2). Individuals at sample B1 had significantly lower values for TL, SL, and W, but the highest condition factor in May ( $K$ =1.22; Table 2).

In October, sample B1 still had significantly lower TL, SL and W than other pooled samples, and significantly higher Fulton's $K$ compared to the pooled Antioche, but not other Pertuis Breton samples (Table 2). Conversely, in October, significant differences were recorded among the Pertuis d'Antioche and Pertuis Breton (B2, B3, B4) samples for each variable, including Fulton's $K$ (all $P<0.001$; Table 2). Such a difference was especially sensitive for body mass (Fig. 2). 
Regardless of the very particular position of sample B1, Pertuis d'Antioche and Pertuis Breton samples were not significantly phenotypically differentiated in May, whereas they were significantly differentiated in October for each variable $(P<0.001)$. Phenotypic differentiation therefore was more pronounced with time spent by the YOY sole in each nursery, also indicating that habitat quality strongly differed among nurseries.

\subsection{Genetic data: preliminary analyses within each nursery}

Allele numbers ranged from 13 (MT; allele size range: 129-143bp) to 26 (Sos3; allele size range: 169-239bp), with locus Sos11 presenting higher gene diversity than other loci (Table 3). Based on biological results (Table 2; Fig. 2), we screened the genetic individuality of samples within each strait. Indeed, Amara et al. (1994) indicated that colonisation of nurseries resulted from a single reproductive event in sole. We focused primarily on population structure in May within each nursery, as understanding the temporal evolution of genetic differentiation to October depends on this initial stage. We therefore especially tested: (i) whether initial samples (Table 1) were genetically differentiated among each other within each nursery in May, and (ii), because of the results obtained at the phenotypic level (Table 2, Fig. 2), whether sample B1 was genetically differentiated from other Pertuis Breton samples in both May and October. In May, samples A1 to A3 or B1 to B4 were not significantly genetically differentiated within each pertuis $(\hat{\theta}=0.0098$; $95 \% \mathrm{CI}$ : $-0.0047-0.0216$; $P=0.110$ for Antioche samples; and $\hat{\theta}=0.0074 ; 95 \% \mathrm{CI}:-0.0069-0.0233 ; P=0.262$ for Breton samples). Merging together samples B2, B3, B4 before comparison with sample B1 did not change

the outcome of the tests $(\hat{\theta}=-0.0023, P=0.646)$. No consistent LD was recorded in May within each initial sample, among initial samples within each nursery, or after 
pooling samples B2 to B4 before comparison with sample B1 in Pertuis Breton (2 significant tests over 17 multilocus tests after correction for multiple tests; details not shown). For October samples, preliminary results for genetic differentiation and LD within individual samples or among samples within each nursery yielded very similar results to those reported for May and therefore are not reported.

Based on these observations, the B1 sample was not treated separately in subsequent genetic analyses, as was done for the phenotypic data (Fig. 2). Samples were then pooled by location (Pertuis Breton, Pertuis d'Antioche) and by date (May, October), leading to four different samples: $\mathrm{BM}, \mathrm{BO}, \mathrm{AM}$, and $\mathrm{AO}$ (Table 1). Genetic differentiation among nurseries was then investigated after pooling.

\subsection{Allelic diversity and Hardy-Weinberg equilibrium in pooled samples}

Deviations from HWE as estimated by significant $\hat{f}$ values were found in all pooled samples for the multilocus estimates derived from the uncorrected data set (Table 3). Results at individual loci demonstrated that this observation depended on significant departures of HWE due to deficit in heterozygotes occurring at the Sos3 locus. Analyses using the Micro-Checker software indicated that HWE deviations at locus Sos3 were due to the presence of a null allele. Locus $M T$ was also affected by a null allele, but deviation of HWE was significant only for Antioche samples, AM and AO. The significance for AM sample was only supported with a one-tailed test $(\alpha=0.025)$, but not a two-tailed test ( $\alpha=0.05$; Table 3 ). The presence of a null allele at the intronic MT locus can, however, be questioned. Primers were defined in exons, making the presence of a null allele unlikely. According to results reported in Table 3 for the AM and AO samples, the null allele frequencies estimated by the FreeNA software were $31.6 \%$ and $18.4 \%$. Such estimates would lead to $9.98 \%$ and $3.39 \%$ of null homozygotes (i.e. non-amplifying individuals; 6.4 and 2 individuals in the AM and AO samples, respectively). Only two 
non-amplifying individuals were observed in both cases, making the presence of a null allele at locus $M T$ potentially unlikely. Nevertheless, to more convincingly analyse data, we hereby reported results for the original, uncorrected data set, then results for a nullallele corrected data set for loci Sos3 and MT. No significant LD was found among nurseries, both in May and October, when considering both data sets (all $P$ 's $>0.05$; details not reported).

\subsection{Gene diversities: uncorrected vs null allele corrected estimates}

Details pertaining to uncorrected gene diversity and corrected gene diversity over 25 replicates are summarized in Table 3. As expected, simulations that added a new allele in frequency distributions at Sos3 and MT loci generally led to higher estimates of $\bar{H}_{\text {obs corr. }}$ than $\mathrm{H}_{\mathrm{obs}}$ uncorr. (Table 3). In all cases, except one at locus Sos3, uncorrected values of gene diversities ( $\mathrm{H}_{\mathrm{obs}}$ uncorr. $)$ belonged to the 95\% CI of the twenty-five simulated data used to compute $\bar{H}_{\text {obs corr. }}$ at each locus and in each population. This indicates little impact of null alleles on gene diversities, but also that data were accurately simulated for useful comparisons of populations. Use of simulated data sets proved that locus $M T$ was the only case reporting significant reduction in gene diversity for the AM-AO comparison $\left(\bar{H}_{\text {obs corr. }} \pm \mathrm{SD}=0.7752 \pm 0.0677\right.$ and $0.5937 \pm 0.0706$, respectively, $P<0.025$ ), but not in the BM-BO comparison $\left(\bar{H}_{\text {obs corr. }} \pm \mathrm{SD}=0.7249 \pm 0.0590\right.$ and $0.6603 \pm 0.0773$, respectively, $P=0.278$ ) (Table 3). Hence, the reduction in gene diversity also observed for the uncorrected data set did not obligatorily translate to significant reduction of gene diversity in the case of locus $M T$ (Table 3). Microsatellite loci did not show this reduction in genetic diversity when comparing $\mathrm{AM}$ to $\mathrm{AO}$ or $\mathrm{BM}$ to $\mathrm{BO}$ estimates for uncorrected data sets (Table 3).

\subsection{Population differentiation: uncorrected vs null allele corrected estimates}


Uncorrected and two distinct null allele-corrected data sets were also used to estimate levels of population differentiation among biologically relevant situations, i.e. comparing samples taken in each area at each date, and comparing samples within area at each date. Results are reported in Fig. 3. Using corrected or uncorrected methods, multilocus and results at each individual locus indicate that YOY sole colonizing the Charentais Straits in May belong to a panmictic population, as no significant genetic differentiation was recorded among the $\mathrm{AM}$ and $\mathrm{BM}$ samples (uncorrected: $\hat{\theta}=-0.0006$; null allele corrected: $\hat{\theta}_{\text {corr.FreeNA }}=0.0015 ; \bar{\theta}_{\text {corr.repl. }}=-0.0018$; Fig. 3). However, results using each method also demonstrated that YOY sole inhabiting each strait were significantly genetically differentiated in October (AO-BO comparison; uncorrected $\hat{\theta}=0.0109, P=$ 0.018; null allele corrected: $\hat{\theta}_{\text {corr.FreenA }}=0.0072, P=0.034 ; \bar{\theta}_{\text {corr.repl. }}=0.0065, P=0.023$ ), and that such genetic differentiation is supported by the $M T$ locus in both cases (uncorrected $\hat{\theta}=0.0401, P<0.01$; null allele corrected: $\hat{\theta}_{\text {corr.FreevA }}=0.0326, P<0.01$; $\bar{\theta}_{\text {corr.repl. }}=0.0274 ; P<0.01$ ) (Fig. 3). Both the use of the ENA correction and estimation of differentiation based on simulated data sets (Fig. 3B) corrected for the significant genetic differentiation observed at locus Sos3 for the AM-AO comparison (Fig. 3A), and provided an illustration of a correction of a spurious significant $F_{\text {st }}$ estimate due to a null allele, as discussed in Chapuis and Estoup (2007).

\section{DISCUSSION}

The Charentais Straits suffer heavy anthropogenic disturbance that affects the health, demography, and population size (density) of the resident biota. As YOY sole have strong fidelity to nurseries (e.g. Coggan \& Dando, 1988; Vinagre et al. 2008; see Durieux 
et al. 2010b for experimental behavioural observations), they cannot escape environmental stressors (Yamashita et al., 2001; Claireaux et al. 2004). In the case of the Charentais Straits, which show variation in the degree of heavy metals contamination and in their bioavailability to organisms (see Introduction section), the results demonstrated phenotypically and genetically similar YOY individuals at the onset of nursery colonisation in May, but phenotypically and genetically differentiated populations among nurseries in October.

\subsection{Within- and among-nursery trends for growth variables and condition}

It has been repeatedly affirmed that performance, density, fitness and/or growth patterns of YOY sole are constrained by environmental factors in the Charentais Straits (Le Pape et al., 2003a; Gilliers et al., 2006a, 2006b; Durieux et al., 2007; Laffargue et al., 2007), but how they differed before and after the summer season has not been clearly demonstrated among these adjacent sites (but see Durieux et al., 2010a). Laffargue et al. (2007) investigated the temporal evolution of growth traits and condition factor in the Pertuis Breton sites compared to experimental individuals raised in mesocosms, but not with Pertuis d'Antioche. Gilliers et al. (2006b) investigated a single cohort of YOY sole at several nurseries including the Charentais Straits, but for a single occasion during the year (after summer). The present study therefore provides both a spatial and temporal investigation of phenotypic variation in YOY sole at a local scale highlighting both within and among straits phenotypic differentiation (see also Durieux et al., 2010a). Such small scale spatial variation in growth/habitat quality has already been reported in various geographic locations for flatfish (Malloy et al., 1996; Yamashita et al., 2003; Vinagre et al., 2008b). By October, lower growth related traits and condition were observed in the Pertuis d'Antioche compared to Pertuis Breton. We hypothesise that higher bioavailability of heavy metals and other events such as, e.g., hypoxia that may 
occur in Pertuis d'Antioche (Soletchnik et al., 1998) could lead to reduced growth and condition among resident individuals. Such relationships have been widely documented in fish (e.g. Sherwood et al., 2000; Lizardo-Daudt and Kennedy, 2008; Amara et al., 2009; but see Pyle et al., 2008), possibly because of interference between heavy metals including $\mathrm{Cd}$ but also $\mathrm{Zn}$ and $\mathrm{Cu}$, metallothionein, and, for example, growth hormone (Vergani et al., 2009).

Role of early settlement in shaping early phenotypic differentiation is exemplified by the substrate type. Indeed, the originality of the Pertuis Breton's B1 sample is not genetic, and very probably arose as it was sampled from a sandy area distant from the Aiguillon Cove (Fig. 1). The Aiguillon Cove, from whence sample B3 originates, was the most effective habitat for YOY sole within Pertuis Breton (Durieux et al., 2010a), as also demonstrated for molluscs (e.g. Mouneyrac et al. 2000; Roméo et al. 2003). Indeed, individuals from this station were heavier and larger than other individuals in October, but the Aiguillon Cove also had the highest density in YOY sole in October whereas sample B1 had the lowest, indicating poor habitat conditions (Durieux et al., 2010a). The nature of the substrate and probably the associated benthic preys appeared to induce density and phenotypic changes in sole, with some phenotypic changes at sample B1 being larger than changes found among straits (Fig. 2).

\subsection{Trends in genetic diversity and differentiation across the two straits}

Morgan et al. (2007) proposed a general schedule involving a decrease in gene diversity and an increase in genetic differentiation at target loci as responses to stress and contamination gradients resulting from a point-pollution source (Fig. 4). Data provided in this study permit this model to be tested, as each strait may represents a particular position in a gradient for heavy metals concentration/bioavailability, relative to a contamination source (the Gironde estuary), but also in a gradient of bioavailability to 
various heavy metals (see the Introduction section). Data add a temporal dimension to this model as Guinand et al. (2008) proposed that sole may behave panmictically at a global scale, but that fish may encounter selective factors that would generate locusspecific differentiation after some time spent on each specific nursery (i.e. at a particular locale in the contamination/bioavailability gradient). We are not aware of further studies documenting the temporal dynamics of genetic differentiation across differentially contaminated sites in aquatic organisms (but see Derycke et al., 2007). Once careful analysis of genetic data for null alleles and corrected estimation of their frequencies have been performed, genetic data fit Morgan et al.'s model particularly well as samples were found genetically undifferentiated then differentiated in May and October, respectively (Fig. 3). As the ENA correction was primarily developed to discard cases of spurious genetic differentiation due to null alleles (Chapuis and Estoup, 2007), this result indicates that a null allele alone cannot explain differentiation observed at locus MT. Concurrently, spurious differentiation at locus Sos3 has been discarded by applying null allele corrections. Similar corrections also suggested that gene diversity at locus $M T$ differed among season at Pertuis d'Antioche (AM: $\bar{H}_{\text {obs corr. }} \pm \mathrm{SD}=0.7752 \pm 0.0677 ; \mathrm{AO}: 0.5937$ $\pm 0.0706, P<0.025)$, but not at Pertuis Breton (BM: $\bar{H}_{\text {obs corr }}=0.7249 \pm 0.0590$; BO: $0.6603 \pm 0.0773 ; P=0.278$ ) (Table 3 ). No such results were observed at anonymous microsatellite loci.

Contrary to results presented there, studies dealing with contaminant-induced genetic change often found overall depletion of genetic diversity at all investigated markers (the 'genetic erosion' hypothesis; Van Straalen and Timmermans, 2002; examples in e.g., Athrey et al., 2007; Fratini et al., 2008), suggesting that genetic drift, selection for individuals with distinct genetic profiles (homo- vs heterozygotes, inbred vs outbred individuals; discussed in Belfiore and Anderson, 2001), or other processes (relatedness: Bourret et al., 2008; Fratini et al., 2008; inbreeding: Brown et al., 2009) are 
probably responsible for overall loss of gene diversity. As selection is locus-specific (Lenormand, 2002; examples in Martinez and Levinton, 1996; Kohn et al., 2003), genetic differentiation results at locus $M T$ for the sole may support a selective hypothesis in YOY sole. Furthermore, the observed spatio-temporal change in the genetic differentiation and gene diversity of YOY sole occurs only at the target MT locus and may imply a role for this locus - or a linked locus - in local adaptation. This selective hypothesis agrees with the numerous published cases dissecting how selection may operate at MT loci (review in Hoffmann and Willi, 2008). This includes cases of aquatic organisms in which some $M T$ alleles have been shown to respond to selection (oligochaete, Limnodrilus hoffmeisteri: Martinez and Levinton, 1996; Pacific oyster, Crassostrea gigas: Tanguy et al., 2002). It has also been shown that elements located in intron 1 regulated expression of a $M T$ gene and the efficiency of the detoxification process in sea urchin (Strongylocentrotus purpuratus) (Bai et al., 1993). No polymorphisms were screened by Bai et al. (1993), or in fish in which similar regulation patterns have been hypothesized (Olsson and Kille 1997).

Nevertheless, in the present study, the selective hypothesis is still challenged in YOY sole as the AM and AO samples were not found genetically distinct across time periods (Fig. 3). Such observation is difficult to explain in the present state. Together with early phenotypic differentiation discussed in sub-section 4.1, it may indicate that selection could have already acted at or just after settlement over nurseries. Nevertheless, if differential selection occurs among straits, samples AM and BM should also probably demonstrate genetic differentiation at locus MT to fit Morgan et al.'s (2007) model. This was not observed as all estimates of $\theta$ were found not significant (Fig. 3).

Whatever the role of selection, results indicate that the summer period is not only a challenge at the phenotypic level for YOY sole (Laffargue et al., 2007), but also at the molecular level, inducing change in patterns of gene diversity among the Charentais 
Straits. Similar to Claireaux et al. (2004), we hypothesize that YOY individuals will be faced with different energy budgeting conflicts in the two Charentais Straits, which impact on growth in young fishes and, at later life stages, may lead to reduced survival and fitness (Priede, 1977; Xie and Klerks, 2004). Such conflicts may arise from differential sensitivity to bioavailable pollutants, and indirectly from $M T$ itself via the detoxification process, but also from factors such as food availability, density, total lipid content and therefore nutritional status of sole over the nurseries, plus their parasite load (see Durieux et al., 2007). For example, Cd has been shown to impair lipolysis in eels (Pierron et al., 2007), suggesting that detoxification and nutritional status may interact to influence in sole.

\section{CONCLUSIONS}

Small scale spatio-temporal genetic population differentiation was demonstrated in YOY sole inhabiting adjacent nurseries in the Charentais Straits. It paralleled phenotypic differentiation for length, body mass, and Fulton's condition factor. Genetic differentiation was only visible for locus $M T$, a locus closely linked to a gene implicated in heavy metal detoxification, including $\mathrm{Cd}, \mathrm{Cu}$, and $\mathrm{Zn}$ that are present and differentially bioavailable to organisms in the Charentais Straits. Conversely, no differentiation was found for neutral microsatellite loci once accurate correction for null alleles was considered.However if phenotypic and genetic differentiation were generally correlated among nurseries in this study, as has also been demonstrated in flounder (Laroche et al., 2002; Marchand et al., 2003, 2004), we still cannot guarantee at this stage that allele- or genotype-specific effects at locus $M T$ directly explains most of the observed phenotypic variation that can also be observed within nursery without genetic differentiation (as demonstrated by, e.g., sample B1), or will cause any functional impairment that could 
reduce/enhance the ability of YOY sole to respond to environmental perturbation. Further studies of the links between genotype and phenotype and of the selective hypothesis are, therefore, necessary.

\section{Acknowledgements}

Authors thank F. Bonhomme, J.-L. Rolland, and J.-F. Agnèse. We are very grateful to J. Grizon and P. Pinet for their valuable help with field sampling. D. McKenzie provided linguistic advices. We further thank three anonymous referees whose comments improved the manuscript. Genetic data were produced at facilities of the IFR119 Montpellier Environnement Biodiversité. This is publication ISEM2011-XXX from the Institut des Sciences de l’Evolution de Montpellier (CNRS UMR 5554).

\section{References}

Airoldi, L., Beck, M.W. 2007. Loss, status and trends for coastal marine habitats of Europe. Oceanography and Marine Biology Annual Reviews 45: 345-405.

Amara, R., Désaunay, Y., Lagardère, F. 1994. Seasonal variation in growth of larval sole, Solea solea (L.) and consequences on the success of larval immigration. Netherlands Journal of Sea Research 32: 287-298.

Amara, R., Lagardère, F., Désaunay, Y., Marchand, J. 2000. Metamorphosis and estuarine colonisation in the common sole, Solea solea (L.): implications for recruitment regulation. Oceanologica Acta 23: 469-484.

Amara, R., Meziane, T., Gilliers, C., Hermel, G., Laffargue, P. 2007. Growth and condition indices in juvenile sole Solea solea measured to assess the quality of essential fish habitat. Marine Ecology Progress Series 351: 251-258.

Amara, R., Selleslagh, J., Billon, G., Minier, C. 2009. Growth and condition of 0-group European flounder, Platichthys flesus as indicator of estuarine habitat quality. Hydrobiologia 627: 87-98. 
Amiard, J.-C., Geffard, A., Amiard-Triquet, C., Crouzet, C. 2007. Relationship between lability of sediment-bound metals $(\mathrm{Cd}, \mathrm{Cu}, \mathrm{Zn})$ and their bioaccumulation in benthic macroinvertebrates. Estuarine Coastal and Shelf Science 72: 511-521.

Anonymous. 2005. Report of the working group on the assessment of Southern shelf demersal stocks. ICES CM 2006/ACFM:01.

Athrey, N.R.G., Leberg, P.L., Klerks, P.L. 2007. Laboratory culturing and selection for increased resistance to cadmium reduce genetic variation in the least killifish, Heterandria formosa. Environmental Toxicology and Chemistry 26: 1916-1921.

Bai, G., Stuebing, E.W., Parker, H.R., Harlow, P., Nemer, M. 1993. Combinatorial regulation by promoter and intron 1 regions of the metallothionein SpMTA gene in sea urchin embryo. Molecular and Cell Biology 13: 993-1001.

Beattie, J.H., Owen, H.L., Wallace, S.M., Arthur, J.R., Kwun, I.S., Hawksworth, G.M., Wallace, H.M. 2005. Metallothionein overexpression and resistance to toxic stress. Toxicological Letters 157: 69-78.

Beck, M.W., Heck, K.L. Jr, Able, K.W., Childers, D.L., Eggleston, D.B., Gillanders, B.M., Halpern, B., Hays, C.G., Hoshino, K., Minello, T.J., Orth, R.J., Sheridan, P.F., Weinstein, M.P. 2001. The identification, conservation, and management of estuarine and marine nurseries for fish and invertebrates. BioScience 51: 633-641.

Béguer, M., Pasquaud, S., Noël, P., Girardin, M., Boët, P. 2008. First description of heavy skeletal deformations in Palaemon shrimp populations of European estuaries: the case of the Gironde (France). Hydrobiologia 607: 225-229.

Belfiore, N.M., Anderson, S.L. 2001. Effects of contaminants on genetic patterns in aquatic organisms: a review. Mutation Research 489: 97-122.

Belkhir, K., Borsa, P., Goudet, J., Chikhi, L., Bonhomme, F. 2001. Genetix v.4.05. Logiciel sous Windows $^{\mathrm{TM}}$ pour la Génétique des Populations. Université Montpellier 2, Montpellier. available at http://www.univ-montp2.fr/ genetix/.

Bourret, V., Couture, P., Campbell, P.G.C., Bernatchez, L. 2008. Evolutionary ecotoxicology of wild yellow perch (Perca flavescens) populations chronically exposed to a polymetallic gradient. Aquatic Toxicology 86: 76-90.

Boutier, B., Chiffoleau, J.F., Gonzalez, J.L., Lazure, P., Auger, D., Truquet, I. 2000. Influence of the Gironde estuary outputs on cadmium concentrations in the coastal waters: consequences on the Marennes-Oléron bay (France). Oceanologica Acta 23(Suppl.): 745-757.

Brown, A.R., Hosken, D.J., Balloux, F., Bickley, L.K., LePage, G., Owen, S.F., Hetheridge, M.J., Tyler, C.R. 2009. Genetic variation, inbreeding and chemical exposure - combined effects in wildlife and critical considerations for ecotoxicology. Philosophical Transactions of the Royal Society B364: 3377-3390.

Chapelle, A., Lazure, P., Ménesguen, A. 1994. Modelling eutrophication events in a coastal ecosystem: sensitivity analysis. Estuarine Coastal and Shelf Science 39: 529-548. 
Chapuis, M.-P., Estoup, E. 2007. Microsatellite null alleles and estimation of population differentiation. Molecular Biology and Evolution 24: 621-631.

Chen, W.-Y., John, J.A.C., Ling, C.-H., Lin, H.-F., Wu, S.-C., Lin, C.-H., Chang, C.-Y. 2004. Expression of metallothionein gene during embryonic and early larval development in zebrafish. Aquatic Toxicology 69: 215-227.

Claireaux, G., Désaunay, Y., Akcha, F., Aupérin, B., Bocquené, G., Budzinski, H., Cravedi, J.-P., Davoodi, F., Galois, R., Gilliers, C., Goanvec, C., Guérault, D., Imbert, N., Mazéas, O., Nonotte, G., Prunet, P., Sébert, P., Vettier, A. 2004. Influence of oil exposure on the physiology and ecology of the common sole Solea solea: experimental and field approaches. Aquatic Living Resources 17: 335-351.

Coggan, R.A., Dando, P.R. 1988. Movements of juvenile Dover sole, Solea solea (L.), in the Tamar estuary, south western England. Journal of Fish Biology 33: 177-184.

Costa, P.M., Caiero, S., Diniz, M.S., Lobo, J., Martins, M., Ferreira, A.M., Caetano, M., Vale, C., DelValls, T.Á., Costa, M.H. 2009. Biochemical endpoints on juvenile Solea senegalensis exposed to estuarine sediments: the effect of contaminant mixtures on metallothionein and CYP1A induction. Ecotoxicology 18: 988-1000.

Costanza, R., Darge, R., Degroot, R., Farber, S., Grasso, M., Hannon, B., Limburg, K., Naeem, S., O’Neill, R.V., Paruelo, J., Raskin, R.G., Sutton, P., Vandenbelt, M. 1997. The value of the world's ecosystem services and natural capital. Nature 387: 253-260.

Courrat, A., Lobry, J., Nicolas, D., Laffargue, P., Amara, R., Lepage, M., Girardin, M., Le Pape, O. 2009. Anthropogenic disturbance on nursery function of estuarine areas for marine species. Estuarine Coastal and Shelf Science 81: 179-190.

Couturier, C., McKenzie, D.J., Galois, R., Joassard, L., Claireaux, G. 2007. Influence of water viscosity on bioenergetics of the common sole Solea solea: ventilation and metabolism. Marine Biology 152: 803-814.

Coyle, P., Philcox, J.C., Carey, L.C., Rofe, A.M. 2002. Metallothionein: the multipurpose protein. Cellular and Molecular Life Sciences 59: 627-647.

Dabrin , A., Schäfer, J., Blanc, G., Strady, E., Masson, M., Bossy, C., Castelle, S., Girardot, N., Coynel, A. 2009. Improving estuarine net flux estimates for dissolved cadmium export at the annual timescale: application to the Gironde Estuary. Estuarine, Coastal and Shelf Science 84: 429-439.

Dahlgren, C.P., Kellison, G.T., Adams, A.J., Gillanders, A.J., Kendall, M.S., Layman, C.A., Ley, J.A., Nagelkerken, I., Serafy, J.E. 2006. Marine nurseries and effective juvenile habitats: concepts and applications. Marine Ecology Progress Series 312: 291-295.

Dardignac-Corbeil, M.J. 2004. La mytiliculture dans le Pertuis Breton - synthèse des travaux réalisés de 1980 à 1992. Annales de la Société de Sciences Naturelles de Charente-Maritime 2004(Suppl.): 3-79. 
Dempster, A.P., Laird, N.M., Rubin, D.B. 1977. Maximum likelihood from incomplete data via the EM algorithm. Journal of the Royal Statistical Society B39: 1-38.

Derycke, S., Hendrickx, F., Backeljau, T., D’Hondt, S., Camphijn, L., Vincx, M., Moens, T. 2007. Effects of sublethal abiotic stressors on population growth and genetic diversity of Pellioditis marina (Nematoda) from the Westerschelde estuary. Aquatic Toxicology 82: 110119.

Désaunay, Y., Guérault, D., Le Pape, O., Poulard, J.-C. 2006. Changes in occurrence and abundance of northern/southern flatfishes over a 20-year period ina coastal nursery area (Bay of Vilaine) and on the eastern continental shelf of the Bay of Biscay. Scientia Marina 70: 193200.

Díaz, R.J., Rosenberg, R. 2008. Spreading dead zones and consequences for marine ecosystems. Science 321: 926-929.

Dorel, D., Koutsikopoulos, C., Désaunay, Y., Marchand, J. 1991. Seasonal distribution of young sole (Solea solea (L.)) in the nursery ground of the Bay of Vilaine (Northern Bay of Biscay). Netherlands Journal of Sea Research 27: 297-306.

Durieux, E.D.H., Galois, R., Bégout, M.-L., Sasal, P., Lagardère, F. 2007. Temporal changes in lipid condition and parasitic infection by digenean metacercariae of young-of-year common sole Solea solea (L.) in an Atlantic nursery ground (Bay of Biscay, France). Journal of Sea Research 57: 162-170.

Durieux, E.D.H., Bégout, M.-L., Pinet, P., Sasal, P. 2010a. Digenean metacercariae parasites as natural tags of habitat use by 0-group common sole Solea solea in nearshore coastal areas: a case study in the embayed system of the Pertuis Charentais (Bay of Biscay, France). Journal of Sea Research 61(Suppl. 1): S107-S117.

Durieux, E.D.H., Bégout, M.-L. 2010b. Sedentary behaviour establishment in 0-group common sole Solea solea: a laboratory video-tracking study. Journal of the Marine Biological Association of the UK 90 (Sp. Iss.): 1257-1262.

Durrieu, G., Maury-Brachet, R., Girardin, M., Rochard, E., Boudou, A. 2005. Contamination by heavy metals $(\mathrm{Cd}, \mathrm{Zn}, \mathrm{Cu}$, and $\mathrm{Hg}$ ) of eight fish species in the Gironde estuary (France). Estuaries 28: 581-591.

Fratini, S., Zane, L., Ragionieri, L., Vannini, M., Cannicci, S. 2008. Relationship between heavy metal accumulation and genetic variability decrease in the intertidal crab Pachygrapsus marmoratus (Decapoda; Grapsidae). Estuarine Coastal and Shelf Science 79: 679-686.

Garoia, F., Marzola, S., Guarniero, I., Trentini, M., Tinti, F. 2006. Isolation of polymorphic DNA microsatellites in the common sole Solea vulgaris. Molecular Ecology Notes 6: 144-146.

George, S.G., Hodgson, P.A., Tytlet, P., Todd, K. 1996. Inducibility of metallothionein mRNA expression and cadmium tolerance in larvae of the marine toleost, the turbot (Scophthalmus maximus). Fundamental and Applied Toxicology 33: 91 - 99. 
Gibson, R.N. 1994. Impact of habitat quality and quantity on the recruitment of juvenile flatfishes. Netherlands Journal of Sea Research 32: 191-206.

Gilliers, C., Le Pape, O., Désaunay, Y., Morin, J., Guérault, D., Amara, R. 2006a. Are growth and density quantitative indicators of essential fish habitat quality? An application to the common sole Solea solea nursery grounds. Estuarine Coastal and Shelf Science 69: 96-106.

Gilliers, C., Le Pape, O., Désaunay, Y., Bergeron, J.-P., Schreiber, N., Guérault, D., Amara, R. 2006b. Growth and condition of juvenile sole (Solea solea L.) as indicators of habitat quality in coastal and estuarine nurseries in the Bay of Biscay with a focus on sites exposed to Erika's oil spill. Scientia Marina 70 (suppl. 1): 183-192.

Girard, P., Angers, B. 2008. Assessment of power and accuracy of methods for detection and frequency-estimation of null-alleles. Genetica 134: 187-197.

Guinand, B., Rolland, J.-L., Bonhomme, F. 2008. Genetic structure of the common sole (Solea solea) in the Bay of Biscay: nurseries as units of selection? Estuarine Coastal and Shelf Science 78: 316-326.

Halpern, B.S., Walbridge, S., Selkoe, K.A., Kappel, C.V., Micheli, F., D’Agrosa, C., Bruno, J.F., Casey, K.S., Ebert, C., Fox, H.E., Fujita, R., Heinemann, D., Lenihan, H.S., Madin, E.M.P., Perry, M.T., Selig, E.R., Spalding, M., Stenek, R., Watson, R. 2008. A global map of human impact on marine ecosystems. Science 319: 948-952.

Harley, C.D.G., Hughes, A.R., Hultgren, K.M., Miner, B.G., Sorte, C.J.B., Thornber, C.S., Rodriguez, L.F., Tomanek, L., Williams, S.L. 2006. The impacts of climate change in coastal marine systems. Ecology Letters 9: 228-241.

Hedrick, P.W. 2005. A standardized genetic differentiation measure. Evolution 59: 1633-1638.

Hermant, M., Lobry, J., Bonhommeau, S., Poulard, J.-C., Le Pape, O. 2010. Impact of warming on abundance and occurrence of flatfish populations in the Bay of Biscay (France). Journal of Sea Research 64 (Suppl. 1): S45-S53.

Hoffman, A.A., Willi, Y. 2008. Detecting genetic responses to environmental change. Nature Review Genetics 9: 421-432.

Ifremer 2005. Surveillance du milieu marin : travaux du réseau national d'observation du milieu marin. Edition 2005. 48p.

Ifremer 2006. Surveillance du milieu marin : travaux du réseau national d'observation du milieu marin. Edition 2006. 51p.

Klaassen, C.D., Liu, J., Choudhuri, S. 1999. Metallothionein: an intracellular protein to protect against cadmium toxicity. Annual Reviews of Pharmacology and Toxicology 39: 267-294.

Kohn, M.H., Pelz, H.J., Wayne, R.K. 2003. Locus-specific genetic differentiation at $R w$ among warfarin-resistant rat (Rattus norvegicus) populations. Genetics 164: 1055-1070.

Koutsikopoulos, C., Désaunay, Y., Dorel, D., Marchand, J. 1989. The role of coastal areas in the life history of sole (Solea solea (L.)) in the Bay of Biscay. Scientia Marina 53: 567-575. 
Laffargue, P., Lagardère, F., Rijnsdorp, A.D., Fillon, A., Amara, R. 2007. Growth performances of juvenile soles Solea solea under environmental constraints of embayed nursery areas. Aquatic Living Resources 20: 213-221.

Laroche, J., Quiniou, L., Juhel, G., Auffret, M., Moraga, D. 2002. Genetic and physiological responses of flounder (Platichthys flesus) populations to chemical contamination in estuaries. Environmental and Toxicological Chemistry 21: 2705-2712.

Lenormand, T. 2002. Gene flow and the limits to natural selection. Trends in Ecology and Evolution 17: 183-189.

Le Pape, O., Holley, J., Guérault, D., Desaunay, Y. 2003a. Quality of coastal and estuarine essential fish habitats. Estimations based on the size of juvenile common sole (Solea solea L.). Estuarine Coastal and Shelf Science 58: 793-803.

Le Pape, O., Chauvet, F., Mahévas, S., Lazure, P., Guérault, D., Désaunay, Y. 2003b. Quantitative description of habitat suitability for the juvenile common sole (Solea solea, L.) in the Bay of Biscay (France) and the contribution of different habitats to the adult population. Journal of Sea Research 50: 139-149.

Le Pape, O., Chauvet, F., Désaunay, Y., Guérault, D. 2003c. Relationship between interannual variations of the river plume and the extent of nursery grounds for the common sole (Solea solea, L.) in Vilaine Bay. Effects on recruitment variability. Journal of Sea Research 50: 177185.

Lewis, N.A., Williams, T.D., Chipman, J.K. 2006. Functional analysis of a metal response element in the regulatory region of flounder CYP1A and implications for environmental monitoring of pollutants. Toxicological Science 92: 387-393.

Lizardo-Daudt, H.M., Kennedy, C. 2008. Effects of cadmium chloride on the development of rainbow trout Oncorhynchus mykiss early life stages. Journal of Fish Biology 73: 702-718.

Lotze, H.K., Lenihan, H.S., Bourque, B.J., Bradbury, R.H., Cooke, R.G., Kay, S.M., Kidwell, S.M., Kirby, M.X., Peterson, C.H., Jackson, J.B. 2006. Depletion, degradation, and recovery potential of estuaries and coastal seas. Science 312: 1806-1809.

Malloy, K.D., Yamashita, Y., Yamada, H., Targett, T.E., 1996. Spatial and temporal patterns of juvenile stone flounder Kareius bicoloratus growth rates during and after settlement. Marine Ecology Progress Series 131: 49-59.

Marchand, J., Tanguy, A., Laroche, J., Quiniou, L., Moraga, D. 2003. Responses of European flounder Platichthys flesus populations to contamination in different estuaries along the Atlantic coast of France. Marine Ecology Progress Series 260: 273- 284.

Marchand, J., Quiniou, L., Riso, R., Thébaut, M.T., Laroche, J. (2004) Physiological cost of tolerance to toxicants in the European flounder Platichthys flesus, along the French Atlantic coast. Aquatic Toxicology 70: 327-343.

Marchand, J., Evrard, J., Guinand, B., Cachot, J., Quiniou, L., Laroche, J. (2010) Genetic polymorphism and its potential relation to environmental stress in five populations of the 
European flounder Platichthys flesus, along the French Atlantic coast. Marine Environmental Research 70: 201-209.

Martinez, D.E., Levinton J. 1996. Adaptation to heavy metals in the aquatic oligochaete Limnodrilus hoffmeisteri: evidence for control by one gene. Evolution 50: 1339-1343.

McDonald, D.G., Wood, C.M. 1993. Branchial mechanisms of acclimation to metals in freshwater fish. In: Rankin, J.C., Jensen, F.B. (eds.), Fish Ecophysiology. London: Chapman \& Hall. pp. 297-321.

McMillan, A.M., Bagley, M.J., Jackson, S.A., Nacci, D.E. 2006. Genetic diversity and structure of an estuarine fish (Fundulus heteroclitus) indigenous to sites associated with a highly contaminated urban harbor. Ecotoxicology 15: 539-548.

Miramand, P., Guyot, T., Pigeot, J., Bustamante, P., Caurant, F., Ferchaud, R. 2000. Le cadmium dans les réseaux trophiques marins: de la source aux consommateurs. Journal Européen d'Hydrologie 31: 127-146.

Moles, A., Norcross, B.L. 1998. Effects of oil-laden sediments on growth and health of juvenile flatfishes. Canadian Journal of Fisheries and Aquatic Sciences 55: 605-610.

Morgan, A.J., Kille, P., Stürzenbaum, S.R. 2007. Microevolution and ecotoxicology of metals in invertebrates. Environmental Science and Technology 41: 1085-1096.

Mouneyrac, C., Amiard, J.-C., Amiard-Triquet, C. 1998. Effects of natural factors (salinity and body weight) on cadmium, copper, zinc and metallothionein-like protein levels in resident populations of oysters Crassostrea gigas from a polluted estuary. Marine Ecology Progress Series 162: 125-135.

Munaron, D., Dubernet, J.-F., Delmas, F., Stanisière, J.-Y., Scribe, P. 2006. Assessment of the quantities of herbicides and nutrients brought down by the river Charente to the coast and modelling of the dispersion of atrazine in the Marennes-Oléron bay. Cahiers de Biologie Marine 47: 85-92.

Nei, M. 1987. Molecular Evolutionary Genetics. Columbia University Press, New York.

Olsson, P.E. 1996. Metallothioneins in fish: induction and use in environmental monitoring. In: Taylor, E.W. (Ed.). Toxicology of Aquatic Pollution: Physiological, Molecular and Cellular Approaches. Society for Experimental Biology Seminar Series 57. Cambridge: Cambridge University Press. pp. 187-203.

Olsson, P.E., Kille, P. 1997. Functional comparison of the metal-regulated transcriptional control regions of metallothionein genes from cadmium-sensitive and tolerant fish species. Biochimica and Biophysica Acta 1350: 325-334.

Olsson, P.E., Kling, P., Petterson, C., Silversand, C. 1995. Interaction of cadmium and oestradiol$17 \beta$ on metallothionein and vitellogenin synthesis in rainbow trout (Oncorhynchus mykiss). Biochemical Journal 307: 197-203. 
Paetkau, D., Waits, L.P., Clarkson, P.L., Craighead, L., Strobeck, C. 1997. An empirical evaluation of genetic distance statistics using microsatellite data from bear (Ursidae) populations. Genetics 147: 1943-1957.

Pierron, F., Baudrimont, M., Bossy, A., Bourdineaud, J.-P., Brèthes, D., Elie, P., Massabuau, J.C. 2007. Impairment of lipid storage by cadmium in the European eel (Anguilla anguilla). Aquatic Toxicology 81: 304-311.

Pigeot, J., Miramand, P., Guyot, T., Sauriau, P.G., Fichet, D., Le Moine, O., Huet, V. 2006. Cadmium pathways in an exploited intertidal ecosystem with chronic cadmium inputs (Marennes-Oléron, Atlantic Coasts, France). Marine Ecology Progress Series 307: 101-114.

Poulard, J.-C., Blanchard, F. 2005. The impact of climate change on the fish community structure of the eastern continental shelf on the Bay of Biscay. ICES Journal of Marine Science 62: 1436-1443.

Priede, I.G. 1977. Natural selection for energetic efficiency and relationship between activity level and mortality. Nature 267: 610-612.

Pyle, G.G., Busby, P., Gauthier, C., Rajotte, J.W., Couture P. 2008. Seasonal and regional variations of metal contamination and condition indicators in yellowperch (Perca flavescens) along two polymetallic gradients. II: Growth patterns, longevity, and condition. Human and Ecological Risk Assessment 14: 126-145.

Rolland, J.-L., Bonhomme, F., Lagardère, F., Hassan, M., Guinand, B. 2007. Population structure of the common sole (Solea solea) in the Northeastern Atlantic and the Mediterranean Sea: revisiting the divide with EPIC markers. Marine Biology 151: 327-341.

Roméo, M., Mourgaud, Y., Geffard, A., Gnassia-Barelli, M., Amiard, J.-C., Budzinski, H. 2003. Multimarker approach in transplanted mussels for evaluating water quality in Charentes, France, coast areas exposed to different anthropogenic conditions. Environmental Toxicology 18: 295-305.

Sherwood, G.D., Rasmussen, J.B., Rowan, D.J., Brodeur, J., Hontela, A. 2000. Bioenergetic costs of heavy metal exposure in yellow perch (Perca flavescens): in situ estimates with a radiotracer ( ${ }^{137} \mathrm{Cs}$ ) technique. Canadian Journal of Fisheries and Aquatic Sciences 57: 441-450.

Solé Rovira, M., Fernández-Díaz, C., Cañavate, J.P., Blasco, J. 2005. Effects of metallothionein levels and other stress defences in Senegal sole larvae exposed to cadmium. Bulletin of Environmental Contamination and Toxicology 74: 597-603.

Soletchnik, P., Faury, N., Razet, D., Goulletquer, P. 1998. Hydrobiology of the Marennes-Oléron Bay. Seasonal indices and analysis of trends from 1978 to 1995. Hydrobiologia 386: 131-146.

Sulaiman, N., George, S., Burke, M.D. 1991. Assessment of sublethal pollutant impact on flounders in an industrialised estuary using biochemical indices. Marine Ecology Progress Series 68: 207-212. 
Tanguy, A., Boutet, I., Bonhomme, F., Boudry, P., Moraga, D. 2002. Polymorphism of metallothionein genes in the Pacific oyster Crassostrea gigas as a biomarker of response to metal exposure. Biomarkers 7: 439-450.

Usero, J., Izquierdo, C., Morillo, J., Gracia, I. 2003. Heavy metals in fish (Solea vulgaris, Anguilla anguilla, and Liza aurata) from salt marshes on the southern Atlantic coast of Spain. Environment International 29: 949-956.

van Oosterhout, C., Hutchinson, W.F., Willis, D.P.M., Shipley, P.F. 2004. Micro-checker: software for identifying and correcting genotyping errors in microsatellite data. Molecular Ecology Notes 4: 535-538.

Van Straalen, N.M., Timmermans, M.J.T.N. 2002. Genetic variation in toxicant-stressed populations: an evaluation of the "genetic erosion" hypothesis. Human and Ecological Risk Assessment 8: 983-1002.

Vergani, L., Lanza, C., Scarabelli, L., Canesi, L., Gallo, G. 2009. Heavy metal and growth hormone pathways in metallothionein regulation in fish RTH-149 cell line. Comparative Biochemistry and Physiology C149: 572-580.

Vinagre, C., Salgado, J., Costa, M.J., Cabral, H.N., 2008a. Nursery fidelity, food web interactions and primary sources of nutrition of the juveniles of Solea solea and S. senegalensis in the Tagus estuary (Portugal): a stable isotope approach. Estuarine, Coastal and Shelf Science 76: 255-268.

Vinagre, C., Fonseca, V., Maia, A., Amara, R., Cabral, H., 2008. Habitat specific growth rates and condition indices for the sympatric soles Solea solea (Linnaeus, 1758) and Solea senegalensis (Kaup 1858), in the Tagus estuary, Portugal, based on otolith daily increments and RNA-DNA ratio. J. Appl. Ichthyo. 24, 163-169.

Wang, W.-X., Rainbow, P.S. 2008. Comparative approaches to understand metal bioaccumulation in aquatic animals. Comparative Biochemistry and Physiology C148: 315323.

Weir, B.S., Cockerham, C.C. 1984. Estimating F-statistics for the analysis of population structure. Evolution 38: 1358-1370.

Williams, T.D., Diab, A.M., George, S.G., Godfrey, R.E., Sabine, V., Conesa, A., Minchin, S.D., Watts, P.C., Chipman, J.K. 2006. Development of the GENIPOL European flounder (Platichthys flesus) microarray and determination of temporal transcriptional response to cadmium at low dose. Environmental Science and Technology 40: 6479-6488.

Xie, L.T., Klerks, P.L. 2004. Fitness cost of resistance to cadmium in the least killifish (Heterandria formosa). Environmental Toxicology and Chemistry 23: 1499-1503

Yamashita, Y., Tanaka, M., Miller, J.M. 2001. Ecophysiology of juvenile flatfish in nursery grounds. Journal of Sea Research 45: 205-218. 
Yamashita, Y., Tominaga, O., Takami, H., Yamada, H., 2003. Comparison of growth, feeding and cortisol level in Platichthys bicoloratus juveniles between estuarine and nearshore nursery grounds. Journal of Fish Biology 63: 617-630. 


\section{Legends of the Tables}

Table 1: Summary of YOY soles (Solea solea) caught at each sampling site labelled as in Fig. 1 in May and October 2005. Sites are individually considered in biological and meristic data analysis. In genetic analyses, sampling sites have been pooled for each strait and date, then four main samples retained (BM, BO, AM, AO). See text for further explanation about the pooling or not of samples.

Table 2: Means (bold characters \pm SD) recorded at each variable for each sampling period, May or October. At each time period, the samples A1, A2, and A3, then samples B2, B3 and B4 (Table 1) have been pooled. The B1 sample located in the Pertuis Breton (Fig. 1) has been considered separately from other Pertuis Breton samples B2, B3 and B4 at each sampling date (see 'Results' for details). Significance of $p$-values is indicated for each variable and for each pairwise Tukey's postdoc test comparison after one-way ANOVA on log transformed data. Graphical representation in Fig. 2.

Table 3: Number of alleles per locus, allele size range, and number of alleles per sample (BM, BO, AM, AO) in YOY sole. Uncorrected observed gene diversities ( $\mathrm{H}_{\mathrm{obs}}$ uncorr. $)$ at each locus are reported for the uncorrected data set. Multilocus estimates of uncorrected gene diversity $( \pm \mathrm{SD})$ are also reported and the mean numbers of alleles per sample are

indicated in bold (uncorrected/corrected). Estimates of $f(\hat{f})$ and associated $p$-values indicating significant deviations of HWE in the uncorrected data set are reported for each individual locus, each sample, and in the multilocus case. Estimates of null allele frequency following the method of Dempster et al. (1977) implemented in the FreeNA software (Chapuis and Estoup 2007) are reported only when a null allele was suspected by Micro-checker (van Oosterhout et al. 2004); otherwise: - . Null allele corrected gene 
diversities ( $\bar{H}_{\text {obs corr. }} \pm \mathrm{SD}$; mean over twenty-five replicates) based on simulation are also provided. No correction for null allele was initially introduced at the Sos6 and Sos 11 loci, but generated simulated samples produced data sets that inevitably slightly differed from the original uncorrected data set. Once a null allele was considered, no estimate of $\hat{f}$ was found significant within simulated samples (not reported). Multilocus gene diversity corrected for null alleles ( \pm SD) is also reported. In bold: pairs of values of $\mathrm{H}_{\text {obs corr. }}$ that were found to significantly vary when comparing the AM-AO or BM-BO samples (one-way ANOVA based on 25 replicates). 


\section{Legends of the Figures}

Fig. 1: Map of the Charentais Straits indicating location of May and October sampling sites in Pertuis d'Antioche (A1, A2, A3) and Pertuis Breton (B1, B2, B3, B4).

Fig. 2: Means ( \pm SD) recorded at each variable for each sampling period. Open circle: Pertuis Breton (samples B2, B3, B4); grey circle: sample B1; open square: Pertuis d'Antioche (samples A1, A2, A3). See Table 2 for further details about one-way ANOVA's significance.

Fig. 3: Estimates of multilocus and single locus genetic differentiation among the four retained YOY sole samples for: $\mathbf{A}$ - the uncorrected data set $(\hat{\theta}), \mathbf{B}$ - the different nullallele corrected data sets, first using the ENA method described in Chapuis and Estoup (2007) $\left(\hat{\theta}_{\text {corr.FreesA }}\right)$, then using the mean estimate of differentiation over twenty-five replicated data sets $\left(\bar{\theta}_{\text {corr.epl. }}\right)$. Significant $F_{\text {st }}$ estimates are reported in bold: * and ** indicate $P<0.05$ and $P<0.01$, respectively. In $\mathbf{B}, \hat{\theta}_{\text {corr.FreevA }}$ estimates at the Sos6 and Sos11 loci are given in grey and are identical to estimates reported in $\mathbf{A}$ as no null allele or other cause of genotyping errors were detected at these loci (Table 2). Sampling procedure during production of simulated data sets induced some variability in allelic frequency distributions at the Sos6 and Sos11 loci in each population, and their $\bar{\theta}_{\text {corr.repl. }}$ estimates are then different from estimators for uncorrected data set at these loci.

Fig. 4: Predicted gene diversity (top; light grey) and genetic differentiation (down; dark grey) trends along a spatial gradient from a theoretical point pollution/contamination source. Gene diversity is expected to decrease in the vicinity of the source, according to increasing gradients in stress intensity, contamination and/or bioavailability (in black; 
from $-\rightarrow+++)$. Genetic differentiation among populations is expected to increase and gene diversity to decrease with the associated gradient of putative selective pressures. Generally, strength of gene flow will conflict with selective pressures to homogenise allele frequencies among populations, contributing to lower levels of population differentiation and higher gene diversity level (Lenormand 2002). Depending on the status of the loci investigated (selected vs neutral), observed patterns of gene diversity and genetic differentiation are expected to be distinct. Selected loci are expected to follow the expected trends for gene diversity and genetic differentiation as long as gene flow is low, while neutral loci are expected to be independent of trend as no selective pressure is directly acting on them, making them less sensitive to stress intensity and level of contamination (i.e. no environmentally-driven gene differentiation, no loss in gene diversity). Neutral loci are possibly sensitive to a selective pressure due to environmental stress only if they are linked to a locus being the real target of selection ('hitch-hiking selection'). See text for relevance of those issues in YOY sole of the Charentais Straits. *: genetic differentiation may reach the value of 1 only in the case of two alleles (e.g. Hedrick 2005); we adopted this value to homogenize maximal values taken by gene diversity and genetic differentiation across the figure. Adapted from Morgan et al. (2007). 
Table 1

\begin{tabular}{|c|c|c|c|}
\hline & $\begin{array}{l}\text { Sampling } \\
\text { site }\end{array}$ & $N$ & $\begin{array}{c}N \text { per site } \\
\text { and per period }\end{array}$ \\
\hline \multicolumn{4}{|l|}{ Pertuis Breton } \\
\hline \multirow[t]{4}{*}{ May } & B1 & 30 & \\
\hline & B2 & 6 & \\
\hline & B3 & 9 & \\
\hline & B4 & 19 & $\mathrm{BM}=64$ \\
\hline \multirow[t]{5}{*}{ October } & B1 & 14 & \\
\hline & B2 & 6 & \\
\hline & B3 & 18 & \\
\hline & B4 & 6 & $\mathrm{BO}=44$ \\
\hline & & & $\mathrm{N}_{1}=108$ \\
\hline \multicolumn{4}{|l|}{ Pertuis d'Antioche } \\
\hline \multirow[t]{3}{*}{ May } & A1 & 20 & \\
\hline & $\mathrm{A} 2$ & 18 & \\
\hline & A3 & 29 & $A M=67$ \\
\hline \multirow[t]{4}{*}{ October } & A1 & 20 & \\
\hline & $\mathrm{A} 2$ & 19 & \\
\hline & $\mathrm{A} 3$ & 19 & $\mathrm{AO}=58$ \\
\hline & & & $\mathrm{N}_{2}=125$ \\
\hline
\end{tabular}


Table 2

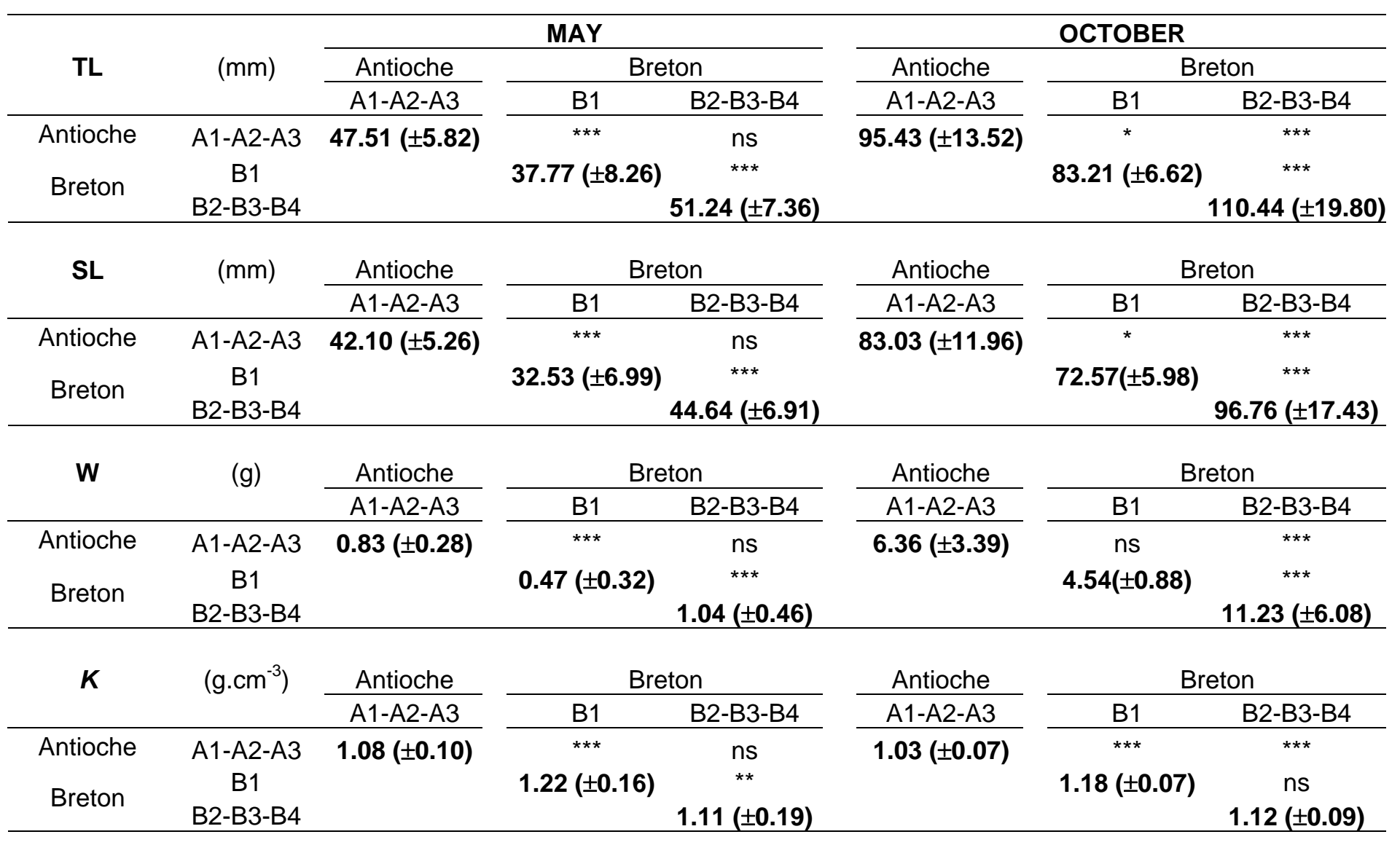

Stars indicate results of multiple comparison Tukey's post hoc test after one-way ANOVA.

With: ns: $P>0.05$; *: $P<0.05$; **: $P<0.01$; ***: $P<0.001$ 
Table 3

\begin{tabular}{|c|c|c|c|c|c|}
\hline Locus & $\begin{array}{l}\text { number of alleles } \\
\text { (allele size range) }\end{array}$ & $\mathrm{H}_{\text {obs uncorr. }}$ & $p$-value & $\begin{array}{c}\text { estimated } \\
\text { frequency } \\
\text { of the null allele }\end{array}$ & $\bar{H}_{\text {obs corr. }} \pm \mathrm{SD}$ \\
\hline
\end{tabular}

Sos3 26

(169-239bp)

$\begin{array}{lllllll}\text { AM } & 22 & 0.7281 & 0.236 & <0.001 & 0.168 & 0.7521 \pm 0.0423 \\ \text { AO } & 20 & 0.6981 & 0.296 & <0.001 & 0.189 & 0.7043 \pm 0.0688 \\ \text { BM } & 18 & 0.6717 & 0.291 & <0.001 & 0.186 & 0.7240 \pm 0.0410^{9} \\ \text { BO } & 21 & 0.7243 & 0.245 & <0.001 & 0.231 & 0.7005 \pm 0.0581\end{array}$

Sos6

18

(175-217bp)

$\begin{array}{lllllll}\text { AM } & 16 & 0.7462 & 0.056 & 0.148 & - & 0.7364 \pm 0.0402 \\ \text { AO } & 14 & 0.7736 & 0.048 & 0.161 & - & 0.7893 \pm 0.0497 \\ \text { BM } & 15 & 0.8153 & 0.021 & 0.255 & - & 0.8007 \pm 0.0376 \\ \text { BO } & 15 & 0.7483 & 0.073 & 0.094 & - & 0.7604 \pm 0.0422\end{array}$

Sos11

16

(218-266bp)

AM 13

AO 13

0.8846

$-0.015$

0.523

$0.8991 \pm 0.0313$

BM 15

0.9020

$-0.091$

0.901

$0.8817 \pm 0.0382$

BO 13

0.9194

$-0.048$

0.780

$0.9065 \pm 0.0398$

$0.9714 \quad-0.108 \quad 0.931$

$0.9442 \pm 0.0476$

MT

13

(129-143bp)

$\begin{array}{lcccccc}\text { AM } & 9 & 0.7415 & 0.124 & 0.035 & 0.116 & \mathbf{0 . 7 7 5 2 \pm 0 . 0 6 7 7} \\ \text { AO } & 6 & 0.5434 & 0.338 & <0.010 & 0.184 & \mathbf{0 . 5 9 3 7 \pm 0 . 0 7 0 6} \\ \text { BM } & 10 & 0.6780 & 0.050 & 0.177 & 0.139 & 0.7249 \pm 0.0590 \\ \text { BO } & 8 & 0.6333 & 0.020 & 0.347 & 0.033 & 0.6603 \pm 0.0773\end{array}$

\begin{tabular}{|c|c|c|c|c|c|c|}
\hline Multilocus & $\begin{array}{l}\text { Mean number of } \\
\text { alleles } \\
\text { (uncorr. / corr.) }\end{array}$ & $\mathrm{H}_{\text {obs uncorr. }} \pm \mathrm{SD}$ & & & & $\bar{H}_{\text {obs corr. }} \pm \mathrm{SD}$ \\
\hline AM & $16 / 16.75$ & $0.7269 \pm 0.1107$ & 0.138 & $<0.001$ & - & $0.7578 \pm 0.1328$ \\
\hline $\mathrm{AO}$ & $13.25 / 14$ & $0.7037 \pm 0.1770$ & 0.147 & $<0.001$ & - & $0.7273 \pm 0.1814$ \\
\hline BM & $15 / 15.75$ & $0.7773 \pm 0.1201$ & 0.085 & $<0.005$ & - & $0.7982 \pm 0.1003$ \\
\hline BO & $13.75 / 14.5$ & $0.7570 \pm 0.1454$ & 0.095 & 0.030 & - & $0.7754 \pm 0.1516$ \\
\hline
\end{tabular}

I: value of $\mathrm{H}_{\mathrm{obs} \text { uncorr. }}$ not comprised in the 95\% confidence interval of the distribution of $\bar{H}$ obs corr. based over twenty-five replicates. 
Fig. 1

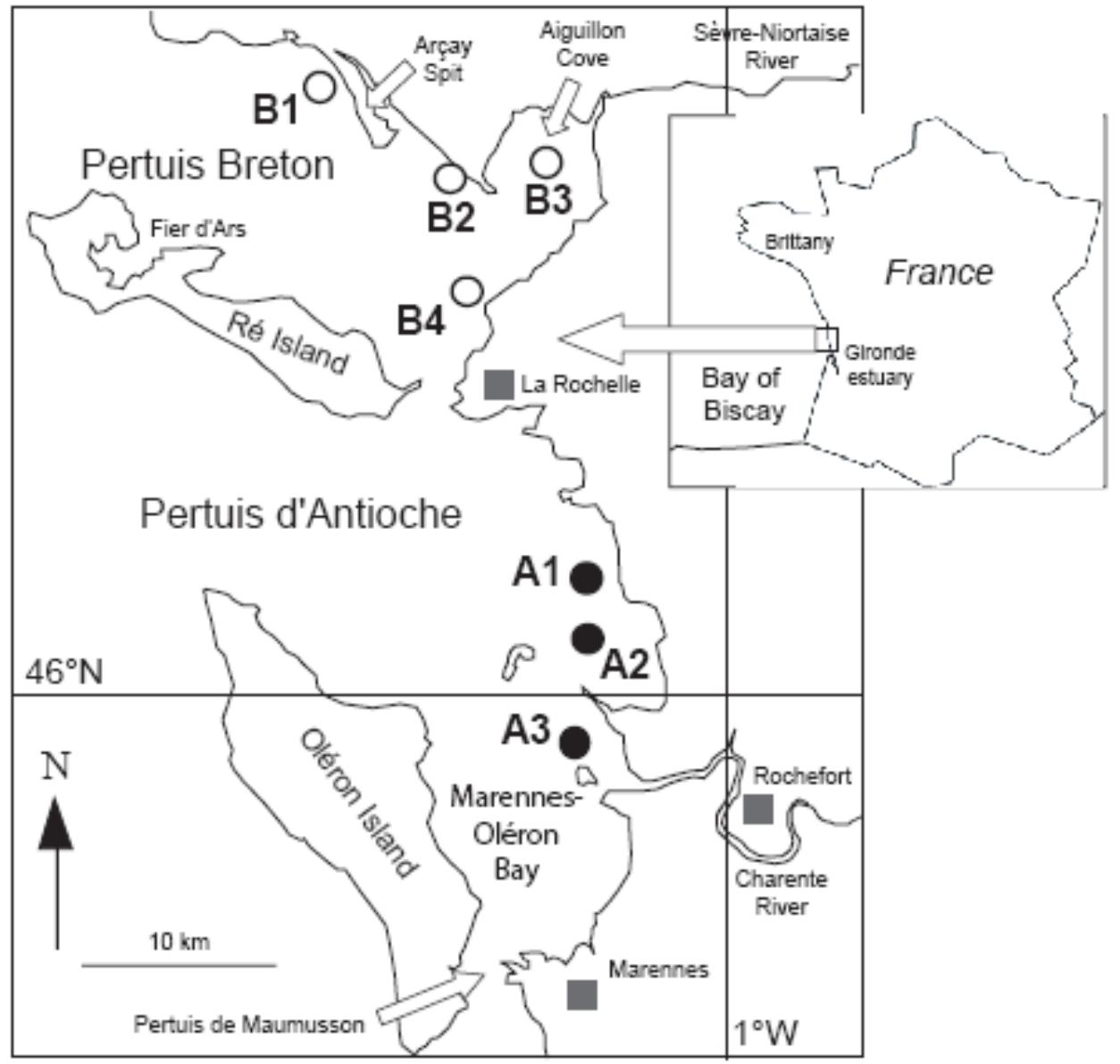


Fig. 2
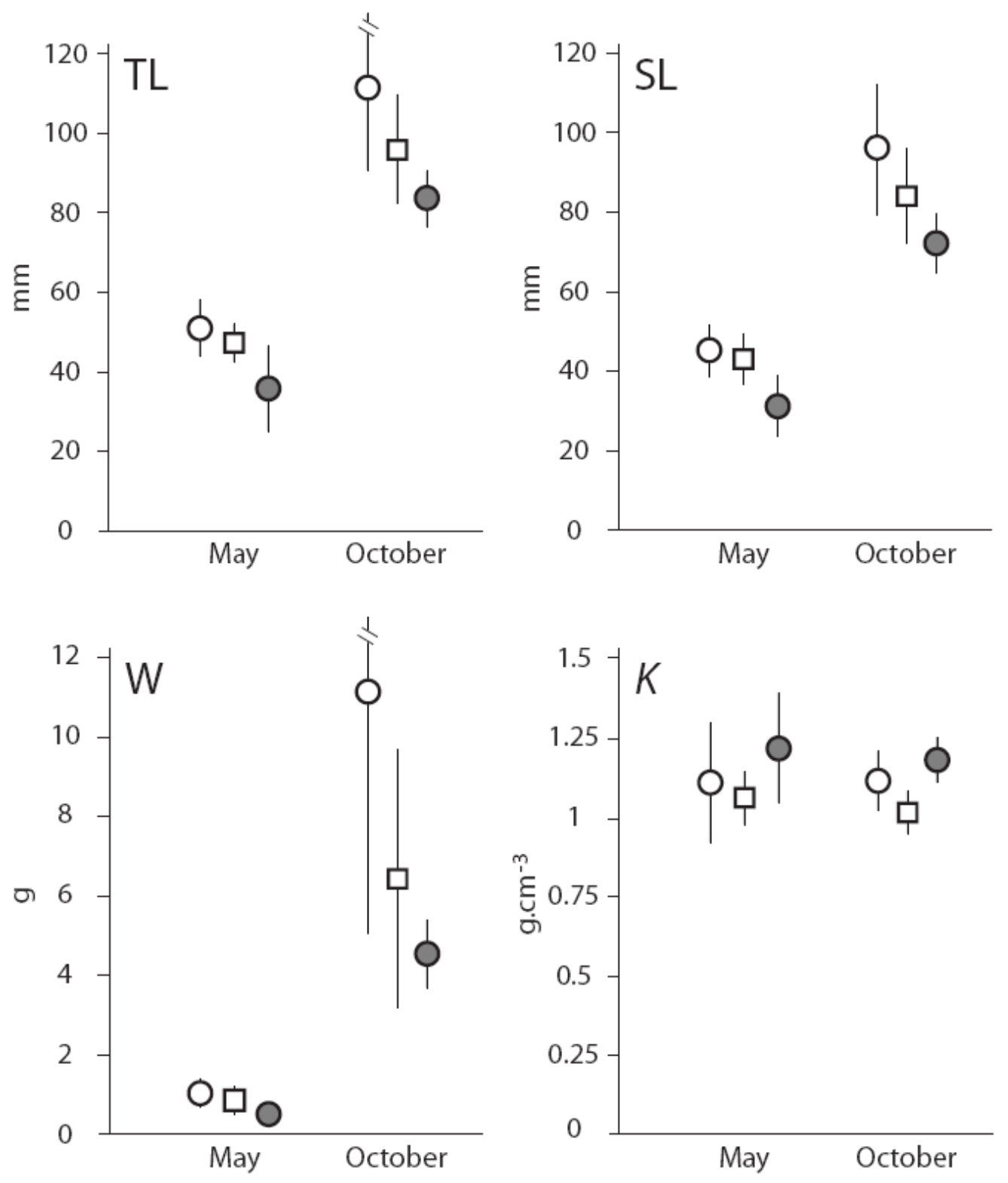
Fig. 3

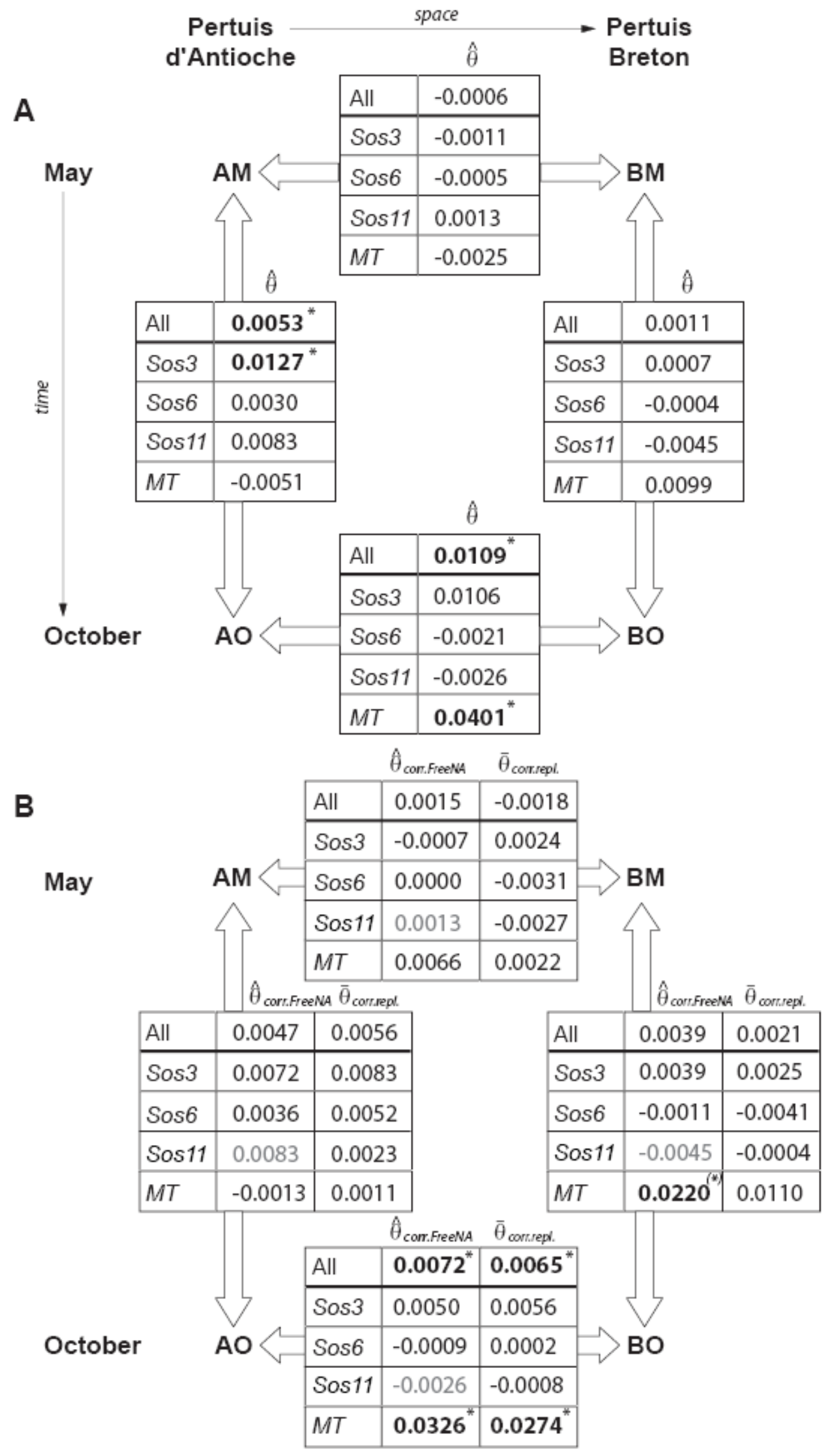


Fig. 4

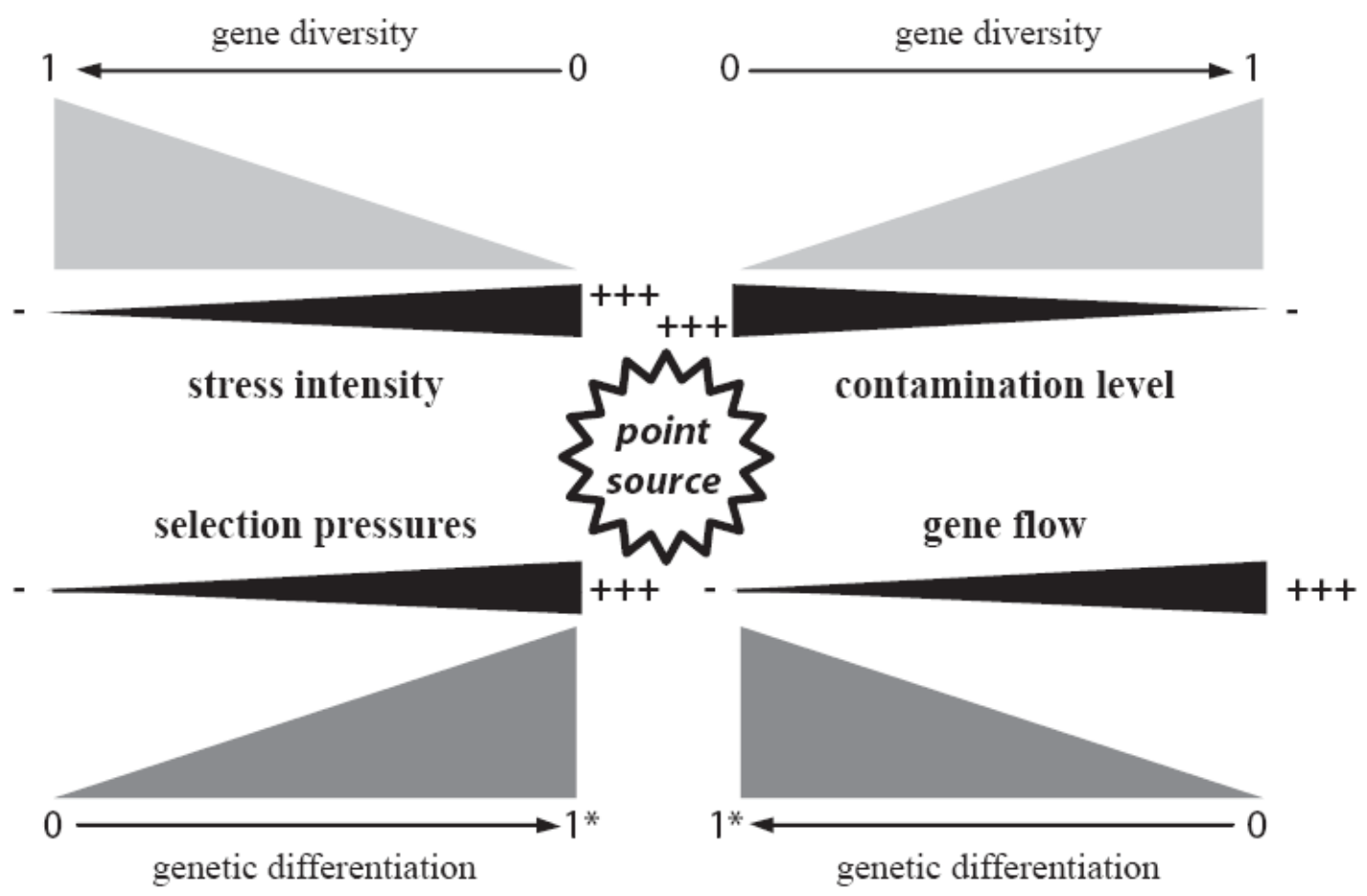

